\title{
Analytical Study of Municipal Solid Waste Characteristics at Deonar Dumping Yard in Mumbai Region, Maharashtra, India
}

\author{
Dabhi Jagrutiben1, Abhay Shelar² \\ ${ }^{1}$ Student, 2 Professor \\ ${ }^{1,2}$ Dept of Civil Engineering, Anantrao Pawar College of Engineering \& Research, Pune, Maharashtra, India
}

\begin{abstract}
How to cite this paper: Dabhi Jagrutiben | Abhay Shelar" Analytical Study of Municipal Solid Waste Characteristics at Deonar Dumping Yard in Mumbai Region, Maharashtra, India" Published in International Journal of Trend in Scientific Research and Development (ijtsrd), ISSN: 2456-6470, Volume-3 | Issue-3, April 2019, pp.1463-1466, URL: https://www.ijtsrd.c om/papers/ijtsrd23 333.pdf

Copyright (C) 2019 by author(s) and International Journal of Trend in Scientific Research and Development Journal. This is an Open Access article distributed under the terms of the Creative Commons Attribution License

(CC BY 4.0)

(http://creativeco

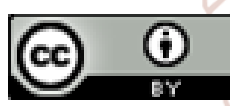

mmons.org/licenses/by/4.0)
\end{abstract}

\section{INTRODUCTION}

Local governments in Asia at present spend about US \$25 billion per year on waste management of the urban area. This amount is used to collect more than 90 percent of the waste in high-income countries \& it is about 50 to 80 percent in middle-income countries, and only 30 to 60 percent for low-income countries in 2025, Asian governments should look forward to spending at least double this amount on solid waste management activities. [2]

Due to change in habitats of people, some researcher's forecasted that between 2020 and 2025 the waste composition of Indian garbage will undergo drastic change. It has been seen that the consumption of inorganic waste is increasing day by day and still we don't have permanent, effective and green solutions over these problems.

Solid waste is directly concern with the health of people living nearby, poorly maintained landfill sites are accountable to groundwater pollution because of leachate production, open dumping of solid waste causes breeding of flies, mosquitoes, cockroach, rats, and other pests, these pests are responsible for spreading of diseases; also open dumping cause's significant air pollution in surrounding area. Direct handling of solid waste can result in various types of infectious and chronic diseases with the waste workers and the rag pickers being the most vulnerable. [3]

The city of Mumbai is located in western India and is the capital of the State of Maharashtra. Mumbai and its neighboring suburbs, together constituting the Greater Mumbai Metropolitan area, inhabits more than 20,7 million people on an area total of 437.71 square kilometers. Geographically, Mumbai is a peninsular city separated from the mainland by the Thane creek and Harbour bay in the east, facing the Arabian Sea to the west and south. The city initially originated as a group of seven islands that were connected by massive land reclamation projects. Hence, the city is low lying with an above sea level height of hardly 10 15 meters, at some places just above sea level. [3]

Deonar dumping yard, India's oldest and largest dumping ground set up in 1927, still in use for dumping municipal solid waste of Mumbai. In our study characteristic of municipal solid waste is focused to better manage the municipal solid waste. 
International Journal of Trend in Scientific Research and Development (IJTSRD) @ www.ijtsrd.com eISSN: 2456-6470

A. Necessity of solid waste management

$>$ Due to growth in population, industrialization \& urbanization, the generation of solid waste has increased threateningly.

$>$ Solid waste has many severe influences over the development of a city or village.

$>$ Diseases, odor pollution, unhygienic surrounding are the major fears arise due to solid waste.

$>$ Major cities in India are producing more than 1000 tonnes per day of solid waste. A major part of this waste is discarded to land dumping which has its own impacts over land, society, and environment.

$>$ Proper SWM provides competence of collection, segregation, transportation, \& treatment of waste suitably.

$>$ This reduces odor pollution \& risk of diseases, also good management improves the aesthetics of the city.

$>$ If not managed appropriately then the concept of a smart city can worsen the situation of the current SWM scenario.

$>$ Though SWM is complex to execute but with appropriate analysis \& study, disciplinary work, and modern eco-friendly techniques. It is possible to achieve needful.

\section{B. Study Objective}

"The ultimate aim of this work is, to study the characteristics of solid waste at Deonar dumping yard by conducting the analytical study in Pre-monsoon and Post-monsoon period"

\section{LITERATURE REVIEW}

A literature review of scholarly articles, books, dissertations, conference proceedings and other resources which are relevant to the study and understanding the characteristics of municipal solid waste and its methodologies is carried out to set the background on what has been explored on the topic so far. An extensive literature review provides background information on current knowledge related to the research topic. On the bases of learning from the literature review, the methodology will be secure and study will be carried out as per the roadmap derived from the review.

The composition percentage derived from various research papers is formulated in tabular form below

Table No. 1: Composition Percentage from Various Research Paper

\begin{tabular}{|c|c|c|c|c|}
\hline \multirow[b]{2}{*}{$\begin{array}{l}\text { Sr. } \\
\text { No. }\end{array}$} & \multirow[b]{2}{*}{ Tittle } & \multirow[b]{2}{*}{$\begin{array}{l}\text { Year of } \\
\text { Publication }\end{array}$} & \multicolumn{2}{|c|}{ Remarks } \\
\hline & & & $\begin{array}{l}\text { Composition of } \\
\text { Solid Waste }\end{array}$ & $\begin{array}{l}\text { Percentage } \\
(\%)\end{array}$ \\
\hline \multirow{6}{*}{1.} & \multirow{6}{*}{$\begin{array}{l}\text { Existing Situation of Solid Waste Management in Pune City, } \\
\text { India by Mane T.T. and Hingane Hemalata N. [12] }\end{array}$} & \multirow{6}{*}{ mal 2012} & Organic Waste & 70 \\
\hline & & & Paper & 8 \\
\hline & & & Plastic & 7 \\
\hline & & & Metal & 4 \\
\hline & & & Glass & 6 \\
\hline & & & Miscellaneous & 5 \\
\hline \multirow{6}{*}{2.} & \multirow{6}{*}{$\begin{array}{c}\text { Extract from the report "Strategic Action Plan for Integrated } \\
\text { Solid Waste Management Plan SN: 2456-647 } \\
\text { (Volume I)" }\end{array}$} & \multirow{6}{*}{2006} & Organic Waste & 65 \\
\hline & & & Paper & 8 \\
\hline & & & $\begin{array}{c}\text { Plastic, Rubber, } \\
\text { Leather \& Synthetic }\end{array}$ & 7 \\
\hline & & & Metal & 6 \\
\hline & & & Glass & 4 \\
\hline & & & Inert material & 10 \\
\hline \multirow{8}{*}{3.} & \multirow{8}{*}{$\begin{array}{c}\text { Revised city development plan - 2041, Maharashtra, under } \\
\text { JNNURM (Report by PMC) } \\
\text { (Source: https://pmc.gov.in/sites/default/files/project- } \\
\text { glimpses/City_Development_Plan) }\end{array}$} & \multirow{8}{*}{2013} & Organic Waste & 33 \\
\hline & & & Paper & 6 \\
\hline & & & Plastic & 5 \\
\hline & & & Metal & 3 \\
\hline & & & Glass & 5 \\
\hline & & & Inert material & 25 \\
\hline & & & Leather/ Rubber & 1 \\
\hline & & & Miscellaneous & 22 \\
\hline \multirow{8}{*}{4.} & \multirow{8}{*}{$\begin{array}{l}\text { Integrated solid waste management (Energy revolution from } \\
\text { municipal solid waste) - Report prepared by Solid Waste } \\
\text { Management department of PMC. (Source: } \\
\text { http://opendata.punecorporation.org/Citizen/CitizenDatasets) }\end{array}$} & \multirow{8}{*}{2016} & Organic Waste & 31 \\
\hline & & & Paper & 6 \\
\hline & & & Plastic & 9 \\
\hline & & & Metal & 3 \\
\hline & & & Glass & 5 \\
\hline & & & Inert material & 23 \\
\hline & & & Leather/ Rubber & 1 \\
\hline & & & Miscellaneous & 22 \\
\hline \multirow{5}{*}{5.} & \multirow{5}{*}{$\begin{array}{l}\text { Urban Solid Waste Management in Mumbai by Yuri Joelsson } \\
\text { and Rebecca Lord }\end{array}$} & \multirow{5}{*}{2016} & Organic Waste & 62 \\
\hline & & & Paper & \multirow{3}{*}{17} \\
\hline & & & Plastic & \\
\hline & & & Metal & \\
\hline & & & Glass & 21 \\
\hline
\end{tabular}




\section{METHODOLOGY}

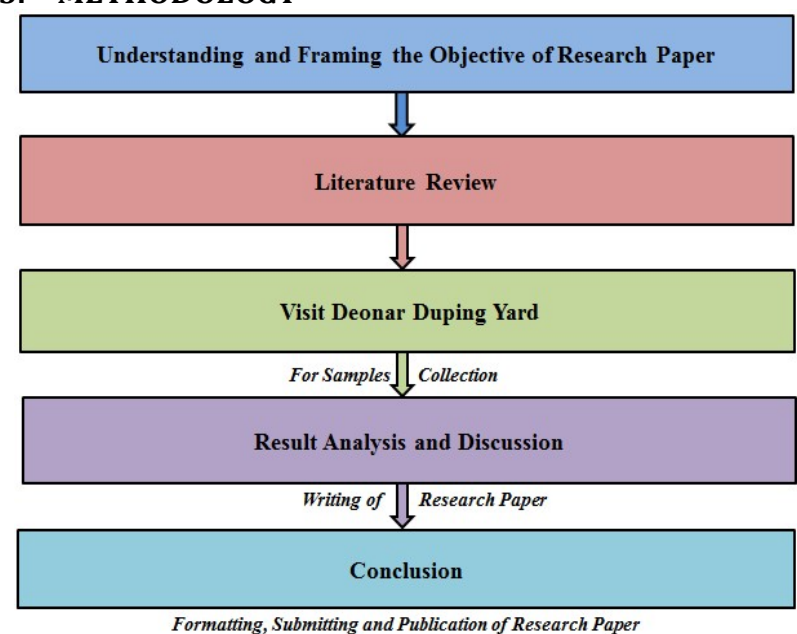

Figure No. 1: Overall Methodology

\section{DATA COLLECTION AND RESULT ANALYSIS}

Mumbai is also known as dream city and the largest city in India has a population of about 18.5 million. Mumbai comprises two regions, the city district which covers an area of 233 square miles and the more extensive Mumbai metropolitan area with a total area of 1681.5 square miles. The city generates 12000 to 13000 tons of solid waste every day.

The characteristics of Deonar dumping yard is studied in Post monsoon and Pre-monsoon analysis.

\subsection{Post Monsoon analysis of waste}

For the post-monsoon analysis, solid waste samples have been collected in the month of June-July 2018 from various locations of Deonar dumping as mentioned in methodology.

\section{A. Composition of solid waste}

Waste composition studies are essential tools for municipal solid waste management. The composition of Mumbai solid waste (as per the report of Solid waste department of BMC) consist about (35 to 40 ) $\%$ of organic matter. Mumbai solid waste consists recyclable about ( 40 to 45 ) $\%$ and the inert material like dust and construction waste is about (10-15) \% of total waste. As Mumbai is known for one of the best educational institutes, it consists about $4 \%$ of paper waste. With rapid urbanization of Mumbai, the percentage of plastic is changing and consist about $10 \%$ of total waste and increase in standard of living of Mumbai city the waste composition of metal and glass is about $3 \%$ and $5 \%$ respectively.

\section{B. Sampling Details:}

> Methodology of Sampling: Manual Sampling

$>$ Quantity of sampling: 10 Numbers of samples.

$>$ Weight of each sample: 1000 grams

$>$ Device used: Sampler Collector, weighing machine

$>$ Precautionary measures:
a. Safety mask
b. Hand gloves
c. Gum boots

$>$ Place of sampling: Random sampling from the recently dumped garbage.

C. Analysis Procedure:

$>$ These samples are collected in polythene bags (Recyclable) \& transported to the laboratory for further analysis.
$>$ In laboratory sorting of material, cleaning of contamination and air dried. Durable items such as glass or plastic container can be washed prior to air drying and filled containers can be emptied of their contents.

> Further in the process waste is classified into twelve categories and then separating all materials as per categories \& weight is measured of each category and recording the same.

\section{Result Discussion}

The primary finding of the sampling is that more than $50 \%$ of waste is organic in nature, the food scrap consists of about $36 \%$ and the yard trim is about $9 \%$. This high potential of biodegradable waste shows the potential for composting. The recyclable composition consists of about $23 \%$ at every place which shows the need for segregation at source. Among the recyclable plastic waste contributes the highest as compared with other recyclable waste.

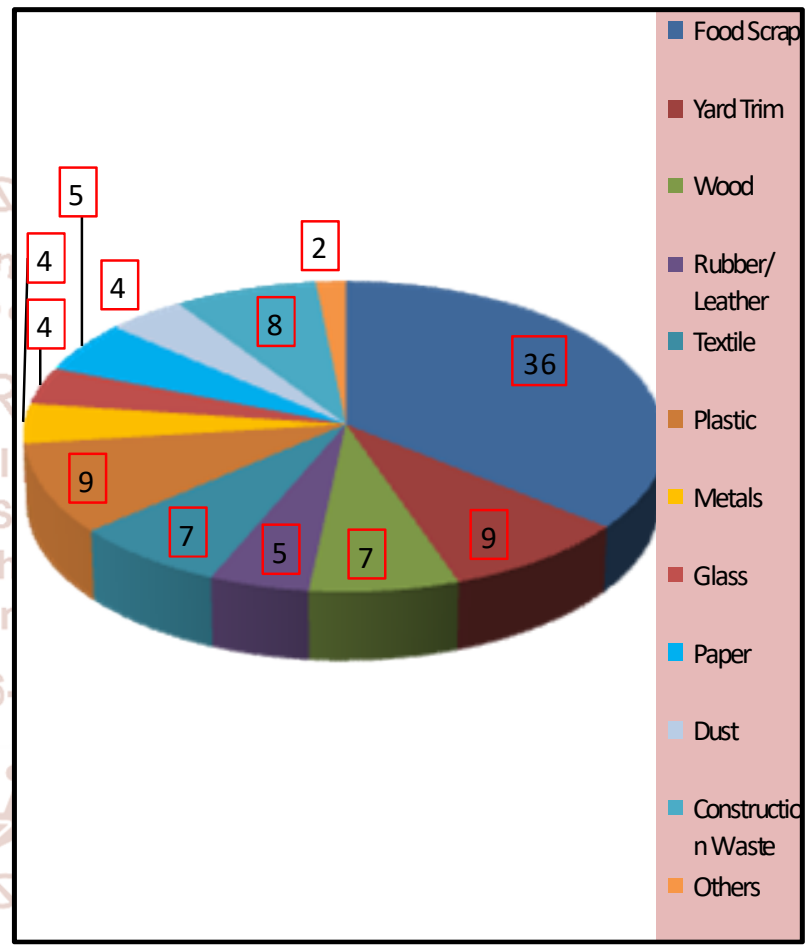

Figure No. 2: Chart showing waste constituents for Composition in Post Monsoon analysis

\subsection{Pre Monsoon analysis of waste}

For the pre-monsoon analysis, solid waste samples have been collected in the month of March-April 2019 from various locations of Deonar dumping and at various places as mentioned in methodology. The sampling details and analysis procedure are the same as post monsoon analysis.

\section{A. Result Discussion}

The primary finding of the sampling is about $48 \%$ waste is organic in nature, the food scrap consists of about $33 \%$ and the yard trim is about $8 \%$. This high potential of biodegradable waste shows the potential for composting. The recyclable composition consists of about $28 \%$ at every place which shows the need for segregation at source. Among the recyclable plastic waste contributes the highest as compared with other recyclable waste. As per the examination of samples, it has been observed that the dust has been increased drastically in some of the samples. 


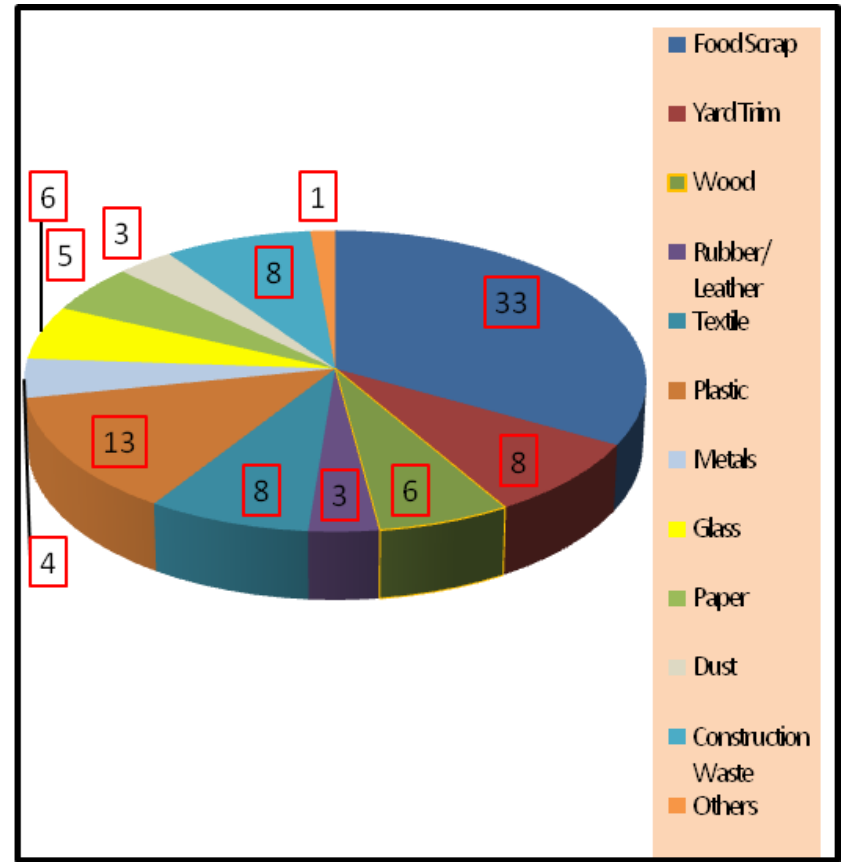

Figure No. 3: Chart showing waste constituents for Composition in Pre Monsoon analysis

\section{CONCLUSION}

Solid waste management is one of the challenging threats in front of the world, the change in habitats of people, rapid development is responsible for the large generation of waste, in Mumbai are generating more than 7,500 MT of waste per day. This waste is creating problems to public health, drainage, aesthetics, of the cities, Proper collection, storage, processing, transport \& disposal of waste will lead to the minimization of waste impacts.

Deonar dumping yard receives 50 - 60 percent of the total waste generated in Mumbai as this is the largest of all the three dumping sites with an area of 111 hectares. Presently the study of Deonar landfill facility for disposal of waste which is not efficiently working.

The waste generated from the city has a particular character; the waste from the city is besides organic one, it also contained some amount of recyclable inorganic part. As per the keen examination of all samples, it has been observed that the values of composition are different in all the randomly selected places. As there is "no one size fits all" and there is always a scope for improvement and learning, which gives the scope for advanced study of municipal solid waste on a larger scale at Deonar dumping yard, with addition of cement, soil etc. to observe the strength gain is the future scope of study.

\section{REFERENCE}

[1] Analytical Study of Solid Waste Management in Pune, India By Mane T. T. and Hingane Hemalata N. (Journal of Environmental Research And Development Vol. 9 No. 04, April - June 2015)

[2] What a waste, solid waste management in Asia by Urban Development Sector Unit East Asia and Pacific Region May 1999.

[3] Urban Solid Waste Management in Mumbai Current challenges and future solutions for Urban Development by Prof. Björn Frostell, Ph.D. Student Jagdeep Singh \& Prof. Anurag Garg.

[4] Solomon Cheru, Assessment of Municipal Solid Waste Management Service in Dessie Town, Addis Ababa University, School Of Graduate Studies, June, 2011.

[5] Lecture Notes for Environmental and Occupational Health Students, Takele Tadesse, University of Gondar2004In collaboration with the Ethiopia Public Health Training Initiative, The Carter Center, the Ethiopia Ministry of Health, and the Ethiopia Ministry of Education.

[6] Daniel Hoornweg and Perinaz Bhada-Tata,what a waste, A Global Review of Solid Waste Management March 2012, No. 15.

[7] Experimental evidence of anisotropy in municipal solid waste by D. Zekkos, University of Michigan, Ann Arbor, USA. Coupled Phenomena in Environmental Geotechnics - Manassero et al (Eds) (C) 2013 Taylor \& Francis Group, London, ISBN 9781138000605

[8] Comparative Analysis of Solid Waste Management in 20 cities By David C. Wilson, Ljiljana Rodic, Anne Scheinberg, Costas Velis and Graham Alabaster. Department of Civil and Environmental Engineering, Imperial College, London, United Kingdom, Wageningen University and Research Centre, Wageningen, the Netherlands, WASTE, Gouda, the Netherlands; UN-Habitat, Nairobi, Kenya.

[9] Problems of Solid Waste Management in Indian Cities By Vijay Kumar, Dr R.K.Pandit Professor, Faculty of Architecture and Planning D.C.R. University of Science and Technology, Murthal, Sonepat, Haryana Professor, Department of Architecture, M.I.T.S Gwalior.

[10] Existing Situation of Solid Waste Management in Pune City, India by Mane T.T.1 and Hingane Hemalata N. Department of Botany, Baburaoji Gholap College, Sangvi, Pune, MS, India and Shree Vinay Engg. Services Pvt. Ltd. working site Tata Motors Pvt. Ltd. Pimpri Pune, MS, India.

[11] Pune's Solid Waste Management By Mr. Rajendra Jagtap and Prof. Dr. Mahesh V. Shitole (Tactful Management Research Journal - ISSN: 2319-7943).

[12] Status and challenges of municipal solid waste management in India: A review by Rajkumar Joshi and Sirajuddin Ahmed, published in Cogent Environmental Science (2016), 2: 1139434 